\title{
Biomass and decay rates of roots and detritus in sediments of intermittent Coastal Plain streams
}

\author{
Ken M. Fritz ${ }^{1,4, *}$, Jack W. Feminella ${ }^{1}$, Chris Colson $^{2}$, B. Graeme Lockaby ${ }^{2}$, Robin Governo ${ }^{2}$ \\ \& Robert B. Rummer ${ }^{3}$ \\ ${ }^{1}$ Department of Biological Sciences, Auburn University, Auburn, AL, 36849-5407, USA \\ ${ }^{2}$ School of Forestry and Wildlife Sciences, Auburn University, Auburn, AL, 36849-5418, USA \\ ${ }^{3}$ USDA Forest Service, Southern Research Station, Auburn University, Auburn, AL, 36849, USA \\ ${ }^{4}$ Present address: USEPA, National Exposure Research Laboratory, 26 W. Martin Luther King, Mailstop 642, \\ Cincinnati, $O H, 45268$, USA \\ (*Author for correspondence: Tel.: +1-513-569-7092; Fax: +1-513-569-7609; E-mail: fritz.ken@epa.gov)
}

Received 10 January 2005; in revised form 23 June 2005; accepted 22 July 2005

Key words: roots, intermittent streams, organic matter processing, detritus, silviculture, riparian buffer

\begin{abstract}
Biomass and breakdown of tree roots within streambed sediments were compared with leaf and wood detritus in three Coastal Plain headwater intermittent streams. Three separate riparian forest treatments were applied: thinned, clearcut, and reference. Biomass of roots (live and dead) and leaf/wood was significantly higher in stream banks than in the channel and declined with depth strata $(0-10>10-20>20$ $30 \mathrm{~cm}$ ). Riparian roots (live and dead combined) contributed on average 24 and $42 \%$ of coarse particulate organic matter (CPOM) biomass within the top $30 \mathrm{~cm}$ of channel and streambank sediments, respectively. Estimated mean surface area of live riparian roots within sediments was $1084 \mathrm{~cm}^{2} \mathrm{~m}^{-3}$. Streambed temperatures showed greater fluctuation at the clearcut site compared to thinned and reference treatments. However, breakdown rates among buried substrate types or riparian treatments did not differ after $1 \mathrm{y}$. Slow decay rates were associated initially with anaerobic conditions within sandy sediments and later with dry sediment conditions. Riparian roots represent a direct conduit between streamside vegetation and the hyporheic zone. In addition to contributing to organic matter storage, the abundance of riparian roots within streambed sediments suggests that roots play an important role in biogeochemical cycling within intermittent headwater streams of the Coastal Plain.
\end{abstract}

\section{Introduction}

Stream ecosystems can be divided into 3 interactive aquatic compartments: channel surface, floodplain and hyporheic (Ward, 1989; Smock, 1990), with the hyporheic zone receiving the least ecological attention. Inputs of allochthonous material to the hyporheic zone typically occur through burial following floods (Metzler \& Smock, 1990). Significant amounts of leaf input to sandy streambeds in Wisconsin $(50 \%)$ and Virginia (21\%) become buried (Herbst, 1980; Metzler \& Smock, 1990). In some systems organic matter storage within stream sediments can be an order of magnitude higher than that found on the surface (Metzler \& Smock, 1990).

Buried leaves have slower processing rates than leaves on the streambed surface (Herbst, 1980; Metzler \& Smock, 1990). Anoxic conditions, compaction leading to decreased surface area for 
microbial colonization, reduced mechanical abrasion, and lower accessibility by macroinvertebrates are all thought to slow processing rates of buried organic matter (Herbst, 1980).

Riparian roots influence surface runoff and groundwater chemistry before entering the stream channel (e.g., Lowrance et al., 1984); however it is unknown if they function as a direct biological conduit across the terrestrial-aquatic interface. Riparian roots can contribute directly to the organic matter pool through sloughing of dead roots and epidermal tissue and release of water-soluble exudates, mucilage, and gases by live roots (Whipps, 1990; Vogt et al., 1991). The proportion of the streambed that can be colonized by riparian trees is especially high within intermittent streams because of higher channel edge-to-width ratios and lower bank heights than larger-order streams. In addition, root turnover may be high for trees bordering intermittent streams. Alternation of wet and dry conditions within intermittent channels can result in high nutrient availability (Cabrera, 1993; Van Gestel et al,. 1993), whereas anaerobic conditions associated with prolonged inundation can cause or accelerate root senescence (Gambrell et al., 1991; McKevlin et al., 1991).

The extensive research on linkage between riparian vegetation and streams has focused primarily on leaf litter and sunlight. In contrast very little is known about the contribution of roots to organic matter pools and dynamics. The primary objective of this study was to examine the ecological importance of riparian roots, in terms of (1) their contributions to the coarse organic matter (CPOM) pool within the streambed and stream banks, and (2) their decay rates relative to that of buried leaves and wood. In addition, this study was designed to assess the influence of riparian forest management on the CPOM dynamics within intermittent streambeds. We hypothesized that overall CPOM biomass will be higher in stream bank than in streambed sediments and would be highest at shallow sediment depths, but the relative contributions of roots to the sediment CPOM pool would increase with sediment depth. Secondly, we hypothesized that root processing rates would be intermediate between leaf and wood, and would decrease with increasing root diameter. Lastly, elevated temperature associated with removal of riparian canopy would result in higher
CPOM processing rates within streambed sediments than in streams with intact riparian canopies.

\section{Methods}

Study sites

The study streams were in 3 contiguous Coastal Plain watersheds (identified as M1, M2, and M3, lat $31^{\circ}, 34^{\prime} \mathrm{N}$, long $87^{\circ}, 25^{\prime} \mathrm{W}$ ) of the Lower Alabama River, Monroe County in SW Alabama USA. Intermittent stream channels and their watersheds were small (stream width $\sim 0.7 \mathrm{~m}$, watershed area: 10-15 ha), and in-stream habitats were mostly $(\sim 75 \%)$ shallow $(0.03 \mathrm{~m})$, low gradient (channel gradient $\sim 0.03 \%$ ) runs. The geology of the study sites is highly fossiliferous, glauconitic, quartz sand with lenses of greenish-gray clay (Scott, 1971). Streambed sediments were predominately fine to coarse sand $(0.35-0.4 \mathrm{~m}$ deep) overlying clay. The streams flowed for $<6$ mo (Nov-May) with mean discharge ranging from 0.01 to $0.08 \mathrm{~m}^{3} \mathrm{~s}^{-1}$. Upland vegetation was dominated by planted loblolly pine (Pinus taeda). The riparian zone was primarily sweetgum (Liquidambar styraciflua), water oak (Quercus nigra), red maple (Acer rubrum), and sweet bay (Magnolia virginiana) with muscadine (Vitis rotundifolia) in the understory. Tree roots found within stream sediments were mostly water oak, but other species, such as sweet bay, loblolly pine, and holly (Ilex opaca), were common. Watershed riparian treatments were applied in August 1999 including: (1) riparian zone thinned (in M1); (2) riparian zone clearcut (in M2); and (3) riparian zone left intact (reference, in M3).

\section{Measurement of CPOM in sediment and sediment scour and deposition}

Live and dead roots and buried leaf + wood CPOM were quantified on Sept 30 and Oct 1, 1998, when channels were dry. Eighteen cores (5.08 $\mathrm{cm}$ diam., $30 \mathrm{~cm}$ depth) were taken from the stream channel and 12 cores from the banks (50 cm lateral to the stream channel) along a 50 $70 \mathrm{~m}$ section of each stream. Undecomposed surface litter was brushed aside prior to taking cores. Cores were stratified into three $10-\mathrm{cm}$ depth 
sections $(0-10,10-20$, and $20-30 \mathrm{~cm})$, placed in plastic bags on ice, and then brought to the laboratory. Sediment CPOM ( $\geq 1 \mathrm{~mm}$ ) was sorted into 3 categories (live roots, dead roots, and leaves/ wood) and quantified as ash-free dry mass (AFDM, Böhm, 1979; Wallace \& Grubaugh, 1996). Live roots appeared firm and had lightly colored tips, whereas dead roots were limp and dark-tipped.

Surface area of live and dead roots were measured for a subset of cores from all 3 streams $(n=28)$ using digitally scanned images and fractal geometry software (WhinRhizo, Regen Instruments, Inc, Quebec, Canada). Regression models were constructed to predict root surface area from root biomass.

\section{Organic matter processing and physicochemical conditions}

Processing rates of buried leaves and roots were determined with a standard litter bag technique (Boulton \& Boon, 1991). Nylon bags (Nylon Net Co., Memphis, TN) were $15 \times 30 \mathrm{~cm}$ and constructed with $6 \mathrm{~mm}$ openings on the upper mesh and $3 \mathrm{~mm}$ openings on the lower mesh. Bags for leaf litter contained $\sim 5 \mathrm{~g}$ of mixed leaves (L. styraciflua: $41 \%$, Q. nigra: $30.3 \%$, A. rubrum: $12.3 \%$, $M$. virginiana: $8.3 \%$, and $V$. rotundifolia: $8 \%$ ), which was consistent with average percentages collected in littertraps among the 3 streams (C. Colson, unpublished data). Abscised riparian leaves used for processing trials were collected in aerial littertraps (monthly from Oct to Dec 1998), pooled among sub-basins, sorted by species, and dried at $\sim 20^{\circ} \mathrm{C}$ for $\geq 90 \mathrm{~d}$ in the laboratory. Two wooden (Betula papyrifera) popsicle sticks (total dry weight $\sim 5.4 \mathrm{~g}$ ) were attached externally to each leaf litter bag.

Live $Q$. nigra roots used for decay measurement were excavated from the 3 streambeds and taken back to the laboratory, where they were rinsed of soil, sorted into 4 diameter size classes (0.6-1, 1-2.5, 2.5-5, and 5-10 mm, cut into 5, 10, 20 , and $20 \mathrm{~cm}$ lengths, respectively), and dried at $\sim 20{ }^{\circ} \mathrm{C}$ for $\geq 90 \mathrm{~d}$ in the laboratory. Root bags contained a total dry weight of $\sim 6 \mathrm{~g}$ of $Q$. nigra roots. Further, the $0.6-1 \mathrm{~mm}$ size class consisted 5 bundles of 10 pieces tethered by nylon thread. Likewise the $1-2.5 \mathrm{~mm}$ size class consisted of 2 bundles of 5 pieces, whereas the 2 larger size classes consisted of single pieces.

Bags were buried and staked $5 \mathrm{~cm}$ below the streambed surface on 8 August 1999 within runs (length: $\sim 5 \mathrm{~m}$ ) of homogeneous depth and current velocity. Litter bags were arranged in 17 rows of 3 bags per row (51 bags per stream), such that litter types were randomly assigned to positions in a Latin Square design to minimize position effects across the channel width. It is important to note that only a single run within each stream was used, and therefore pseudoreplicated, for the among riparian zone treatment comparisons.

Three litter bags of each type (root and leafwood) were collected from each stream at time 0 (to estimate handling loss), and 18, 44, 112, 314, and $366 \mathrm{~d}$. Upon collection popsicle sticks and litter bags were placed individually in plastic bags, stored on ice, and returned to the laboratory. Litter bag contents were gently rinsed with tap water into a $125-\mu \mathrm{m}$ sieve to separate leaves or roots from sediment and fine particulate organic matter. All invertebrates were removed, identified, and invertebrate biomass was estimated using published allometric equations. Leaves, roots, and wood were then dried at $70{ }^{\circ} \mathrm{C}$ for $48 \mathrm{~h}$, weighed, and ashed at $550{ }^{\circ} \mathrm{C}$ for $2 \mathrm{~h}$, and then reweighed to determine AFDM. Processing rates were calculated as change in AFDM using the exponential decay model (Benfield, 1996). Leaves and leaf fragments were sorted by species (identified by leaf margins and venation) and weighed to quantify species-specific percent-remaining dry weight prior to ashing.

Depth below sediment surface was measured for each litter bag at the time of collection, as streambed sediments sometimes shifted, further burying or exposing bags. Hydrologic condition (scored as presence/absence of surface water) sediment redox condition (depth of aerobic sediment, Bridgham et al., 1991), and percent sediment moisture (gravimetric method) were measured on each collection date. Discharge was measured continuously during the study using Vnotch weirs and pressure transducers. Streambed temperature was measured at 5-h intervals using temperature dataloggers (HoboTemp, Onset ${ }^{\circledR}$ Computer Corp., Bourne, MA) buried $5 \mathrm{~cm}$ below the sediment surface. 


\section{Data analysis}

Differences in biomass among live and dead roots and other streambed CPOM were tested using a 3factor ANOVA (PROC GLM, SAS, 2002), with stream (M1, M2, and M3), location (channel and bank), and depth (0-10, 10-20, and 20-30 cm) as main factors tested. Tukey's-multiple comparison test was used to identify where specific differences among treatments resided when significant differences were detected with ANOVA. All analyses were done following confirmation of statistical assumptions. Normality was confirmed using Shapiro-Wilk Test, whereas residuals were plotted to assess inequality of variance (Zar, 1984). Data were log-transformed when they did not meet parametric statistical assumptions. Significance level was set at $\alpha=0.05$ for all statistical analyses.

Analysis of covariance (ANCOVA), with time as the covariate, was used to test if processing rate (k) differed among roots, leaves, and wood within and among streams. Post-hoc tests (Tukey's HSD) were used to determine where specific differences resided if significant differences are found among substrates or streams. Multiple linear regression (PROC REG, MAXR selection, SAS, 2002) was used to assess the relative contributions of ecological factors (cumulative temperature, burial depth, redox condition, sediment moisture, and invertebrate biomass) on processing rates.

\section{Results}

\section{Sediment CPOM}

Total CPOM biomass was significantly higher within streambank sediments than channel sediments $(p<0.0001)$, and decreased with sediment depth $(0-10>10-20>20-30 \mathrm{~cm}$, Tukey's $p<0.05$, Fig. 1). M2 had significantly higher sediment CPOM biomass than the other 2 study streams (Tukey's $p<0.05$, Fig. 1).

Location-specific CPOM biomass varied among streams and depths. However, dead root biomass was significantly higher within stream

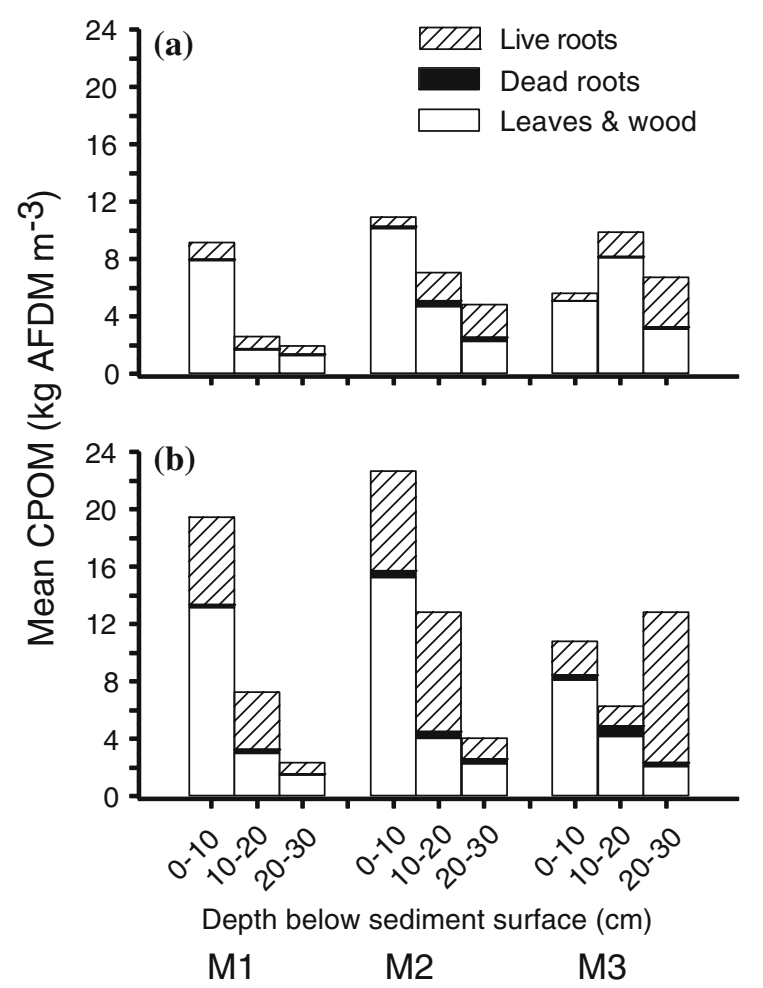

Figure 1. Mean ash-free dry mass (AFDM) of CPOM fractions within sediments of the (a) channel and (b) banks of the 3 study streams among depth strata $(0-10,10-20$, and 20-30 cm) on Sept 30 and Oct 1, 1998. 
banks than streambed sediments $(p<0.0001)$. The relative proportions of leaves + wood to total buried CPOM declined with depth, however this trend was not consistent among streams and locations (Fig. 1). Live and dead roots only contributed $9-14 \%$ of the total organic matter within the top $10 \mathrm{~cm}$ of the streambeds, but this fraction increased to $36-47 \%$ within the deeper strata (Fig. 1a). Roots within streambed sediments were predominately $Q$. nigra ( $>80 \%$ by mass), but also included M. virginiana, I. opaca, and Pinus sp. The percentage of live and dead root biomass within the upper strata of stream banks were twice as great as within channels, but were comparable to streambed percentages at the deeper strata (Fig. 1b).

The relationships between root biomass and surface area were strong for live roots $\left(R^{2}=0.85\right.$, $p<0.0001, n=28)$, but weak for dead roots $\left(R^{2}=0.13, p=0.055, n=28\right)$. Using these relationships, we estimated that the average live and dead root surface area within streambed sediments was 1084 and $296 \mathrm{~cm}^{2} \mathrm{~m}^{-3}$, respectively for the channel habitat and 10,562 and $450 \mathrm{~cm}^{2} \mathrm{~m}^{-3}$ for the live and dead root surface area for the streambank habitat.

\section{Physico-chemical conditions}

Hydrologic conditions differed among streams during the litter bag experiment (Fig. 2). Although the duration of flow measured at the weirs was longer at M1 than M3, this difference was not reflective of conditions at the study reaches, as surface water at M3 was observed on more occasions than at M1 and M2. The effect of riparian management was clearly evident based on daily temperature regimes, where higher fluctuations of streambed temperature were recorded for M2, the watershed where riparian vegetation was removed (Fig. 3). Percent sediment moisture generally reflected hydrologic conditions at the sites (Fig. 4a), whereas redox conditions or depth of aerobic sediment showed a more gradual increase during the experiment (Fig. 4b).

\section{Buried CPOM processing}

All leaf species were still evident after the $112^{\text {th }} \mathrm{d}$, but by the $366^{\text {th }} \mathrm{d}$ there was virtually no sweet bay and muscadine identifiable in litter bags (Fig 5). Water oak was the most recalcitrant of the leaf species, followed by sweet gum and red maple.

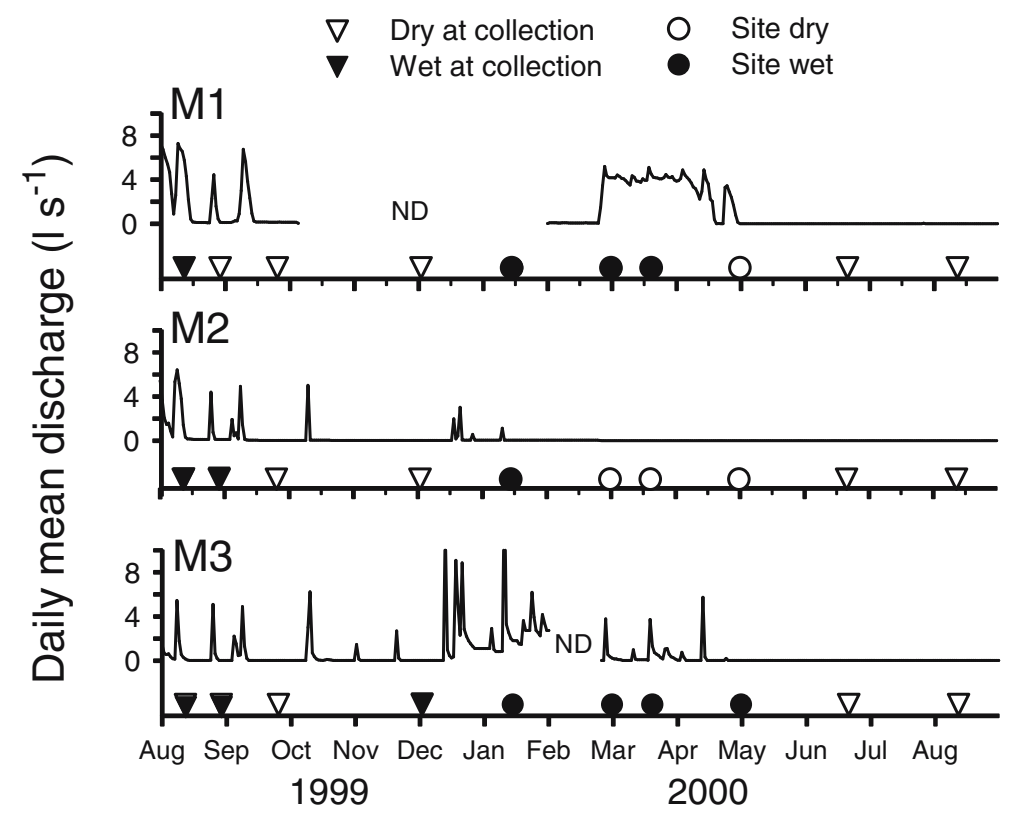

Figure 2. Discharge measured at V-notch weirs for the 3 study streams and observations of hydrologic conditions at study reaches (located upstream of weirs) during the litter breakdown experiment. ND $=$ no data. 

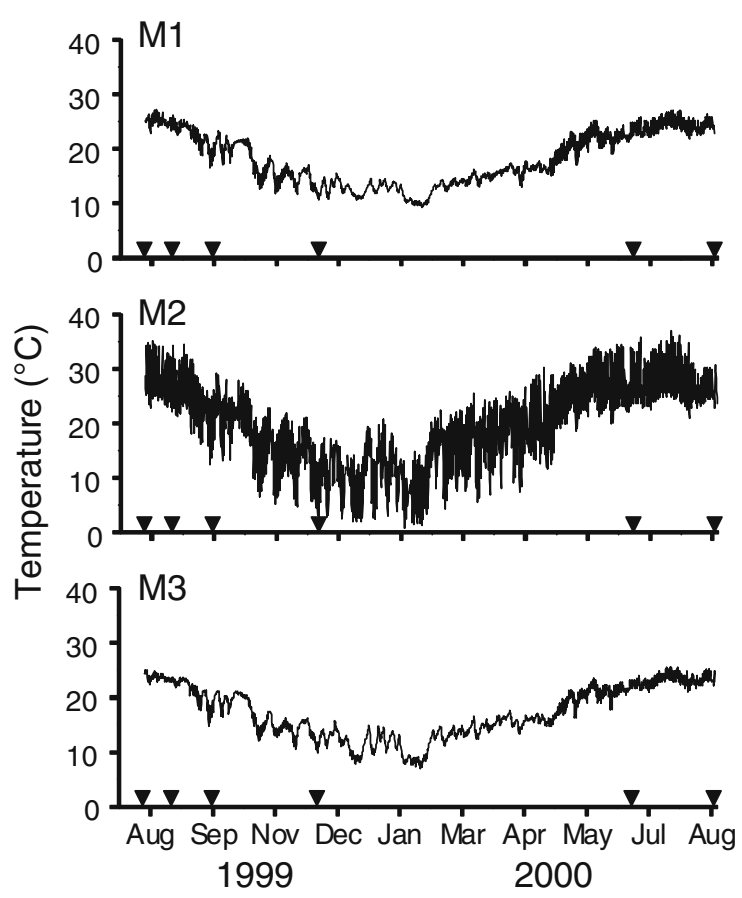

Figure 3. Temperature (5 cm within streambed) measured (5-h intervals) at the study sites during the litter breakdown experiment. Triangles indicate litter breakdown collection dates.

Variation in \% AFDM remaining within streams was low for all substrates during the first $44 \mathrm{~d}$, but began to increase after the $112^{\text {th }} \mathrm{d}$, especially for leaves and wood (Fig. 6). After the $112^{\text {th }} \mathrm{d}$, breakdown of leaves and roots was significantly faster than wood at $\mathrm{M} 2\left(F_{2,30}=6.4, p=0.005\right)$ and $\operatorname{M} 3\left(F_{2,30}=12.9, p<0.0001\right)$. In addition, leaf breakdown differed significantly among streams at the $112^{\text {th }}$ day $\left(F_{2,30}=3.84, p=0.03\right)$, with leaves decaying faster at M3 $(k=0.0052)$ than at M1 $(k=0.0019)$; breakdown in M2 $(k=0.0042)$ did not differ significantly from either of the other streams. At this time period wood appeared to decay faster at M1 than the other streams, however this was not significant $\left(F_{2,30}=2.95, p=0.06\right)$. Exponential decay rates of the substrate types (leaves, roots, and wood) did not differ within or among streams over the entire 1-y period of the experiment (Table 1, Fig. 6). Much of variation in wood mass loss during the last 2 sampling periods likely was associated with colonization of termites on some of the popsicle sticks. Decay rates among root size classes did not differ among or within streams (Table 2, Fig. 7).

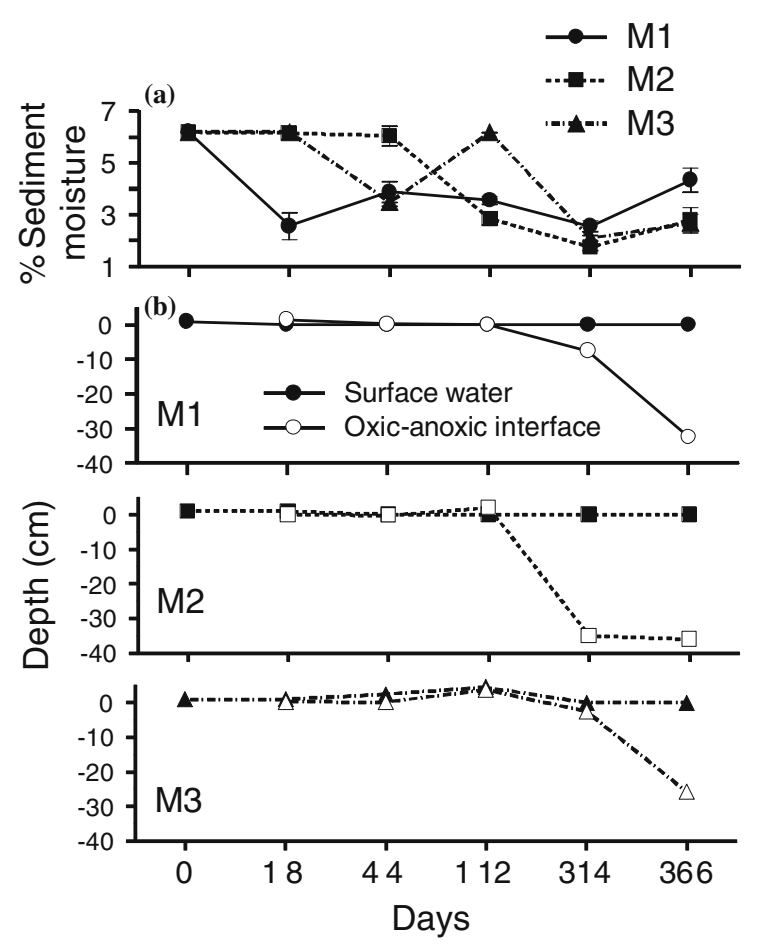

Figure 4. Mean \% sediment moisture (a) and depth to reduction (b) at the study sites during the buried CPOM breakdown experiment. Error bars represent SE $(n=3)$.

There were also no differences among sizes at day 112.

The amount of explained variation in CPOM breakdown by time in the linear and exponential models was comparable for most substrates and streams (Table 3). The addition of cumulative temperature, burial depth of litter bags at retrieval, sediment moisture, redox depth, and invertebrate biomass explained only an additional $1-19 \%$ of the variation in mass loss at M1 and M2. The additional environmental measures however, explained an additional $\sim 30 \%$ of the variation for leaf and root breakdown at M3. Most of the additional explained variation was attributed to streambed temperature and redox condition (Table 3).

\section{Discussion}

The study of intermittent streams represents the interface between stream and soil ecology. Temporally, intermittent headwater streams represent 


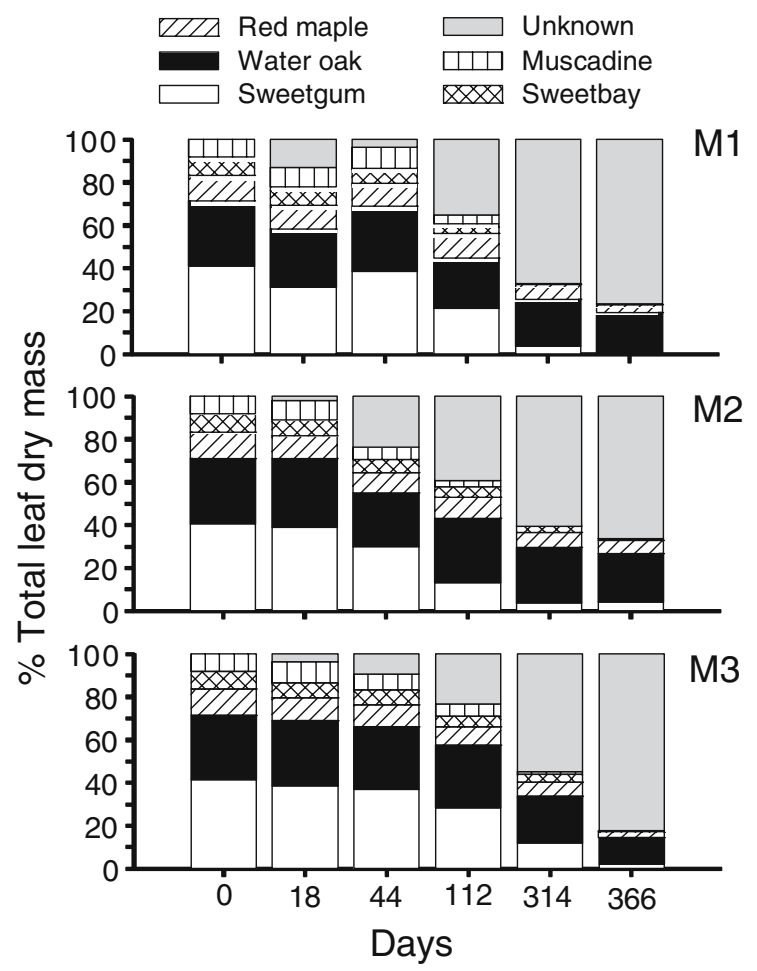

Figure 5. Percentages of leaf species (dry mass) during the buried CPOM breakdown experiment.

the most recent geological transition from terrestrial to aquatic habitats, while also exhibiting both terrestrial and aquatic conditions on an annual basis. Spatially, headwater intermittent streams are analogous to the capillaries of stream networks because of their high channel length to width ratio. Taken together, these characteristics indicate that riparian vegetation should have a significant influence on the ecosystem processes within intermittent streams. Our study examined the extent and contribution of riparian roots to sediment organic matter pool relative to leaves and wood.

The average subsurface $(0-30 \mathrm{~cm}$ deep) CPOM within streambed sediments of our study streams was $6.4 \mathrm{~kg} \mathrm{~m}^{3}$, whereas streambank CPOM was $10.9 \mathrm{~kg} \mathrm{~m}^{3}$. On an areal basis, CPOM within channel sediments was $1.9 \mathrm{~kg} \mathrm{~m}^{-2}$ compared to only $0.3 \mathrm{~kg} \mathrm{~m}^{-2}$ on the channel surface (Fritz \& Feminella, unpublished data). The higher amounts of buried compared to channel surface detritus in our study streams agrees with data collected from 2 Coastal plain streams in Virginia (Metzler \& Smock, 1990; Smock, 1990). Finer sediments of Coastal Plain streams are more likely to shift during spates than coarser sediments of higher gradient streams, therefore retention of organic matter within sediments tends to be greater for low-gradient compared to high-gradient streams.

It has been suggested that temperate intermittent streams have lower retention of benthic CPOM than perennial streams (Hill et al., 1992) because CPOM accumulating in the dry channel is rapidly flushed downstream when flow resumes in the winter or early spring (e.g., Gurtz et al., 1988). However, in channels with fine sediments, a substantial proportion of CPOM entering the channel (Herbst, 1980; Metzler \& Smock, 1990) becomes buried during spates $(25-46 \%)$, therefore depending upon the timing and magnitude of flow resumption and floods CPOM retention may be greater within Coastal Plain intermittent streams than higher gradient intermittent streams with coarser sediment.

Roots were a significant contributor to subsurface organic matter in the channel $(24 \%)$ and banks $(42 \%)$ of our streams. In addition, because of their high surface area, riparian roots may play an important role in nutrient dynamics across the 

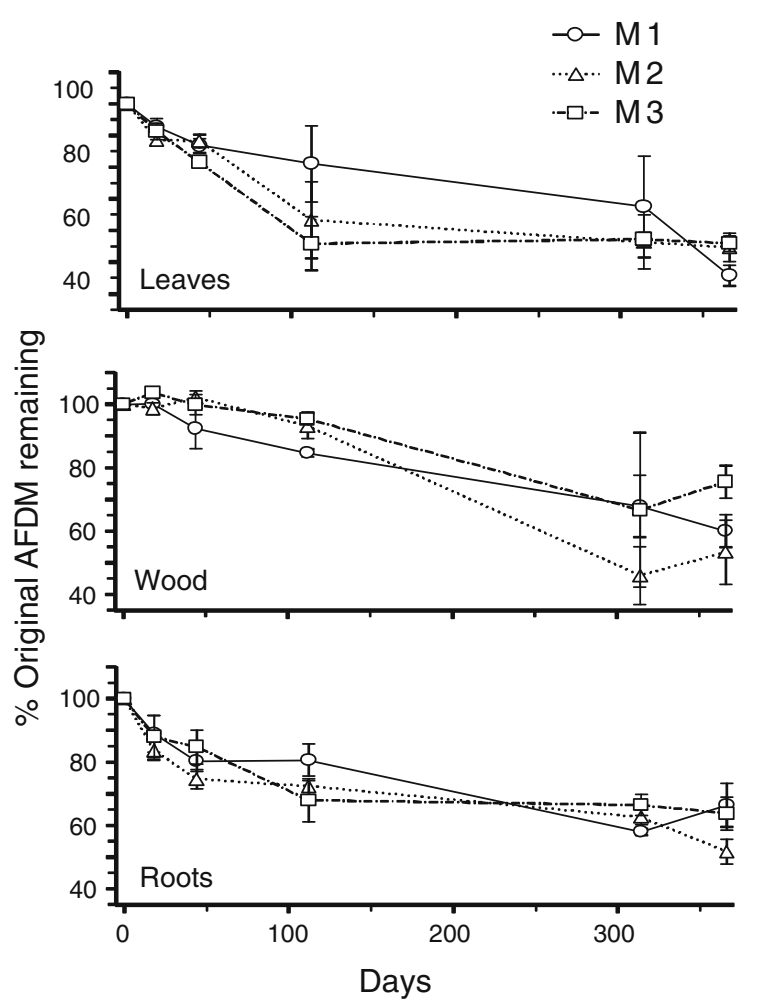

Figure 6. CPOM breakdown of leaves, wood, and roots at the study streams over $1 \mathrm{y}$. Error bars represent $1 \mathrm{SE}$.

terrestrial-aquatic interface through exchange of dissolved organic carbon, nutrients, and water (e.g., Fiebig et al., 1990). We noted that many roots deep within the streambeds were encrusted with iron-deposits, suggesting that these roots are microzones of oxic sediment (Laanbroek, 1990), and thus may support a diverse and active rhizosphere community (Roviva, 1979). We are unaware of any other study that has quantified riparian root biomass within streambed sediments, however several studies in wetland systems have examined belowground biomass of trees. Our overall estimate of root biomass (4.06 Mg AFDM $\mathrm{ha}^{-1}$ ) was comparable to those of nearby forested wetlands. Average belowground standing crop of a swamp tupelo-sweet bay dominated forested wetlands in SW Alabama (3.68-5.21 Mg dry wt ha ${ }^{-1}$ Henson, 1996; 2.0-3.0 Mg dry wt ha ${ }^{-1}$, Jones et al., 1996). Root biomass within forested wetlands declines with depth (Montague \& Day, 1980; Henson, 1996), which differed from root biomass increasing from the $0-10$ to the $10-20 \mathrm{~cm}$ strata in our study. Sediment movement and possibly drainage and soil nutrient levels likely contributes to the different patterns seen in our fluvial system compared to the more poorly drained forested wetlands.

The focus of past litter breakdown studies in intermittent streams has been to compare decay rates with those in perennial streams (e.g., Tate \& Gurtz, 1986; Hill et al., 1988). Many such comparisons have been done in intermittent streams only during the flowing period, and therefore provide only a partial characterization of litter breakdown. Our study has attempted to characterize breakdown over the annual hydrologic conditions (flowing and dry conditions) within intermittent streams and compare realistic (mixed) leaf packs to root breakdown. Breakdown rates of all buried forms of organic matter in this study were slow relative to published rates for leaf litter on streambed surfaces of perennially flowing streams or floodplains. For example, leaf breakdown (using identical species, proportions and collection periods used in present study) measured at the soil surface in the riparian zone of the study streams was 47-64X faster than buried leaf decay

Table 1. Decay coefficients $(k)$ of leaves, wood, and roots for $1 \mathrm{y}$ within the study streams. Data analyzed within and among streams using ANCOVA

\begin{tabular}{|c|c|c|c|c|c|c|}
\hline & \multirow[b]{2}{*}{ Stream } & \multicolumn{3}{|l|}{$k \mathrm{~d}^{-1}(\mathrm{SE})$} & \multicolumn{2}{|c|}{ Within streams } \\
\hline & & Leaf & Wood & Root & $F_{2,48}$ & $p$ \\
\hline & M1 & $0.0018(0.0003)$ & $0.0014(0.0002)$ & $0.0011(0.0002)$ & 1.81 & 0.17 \\
\hline & M2 & $0.0016(0.0003)$ & $0.0023(0.0003)$ & $0.0014(0.0002)$ & 2.96 & 0.06 \\
\hline & M3 & $0.0014(0.0003)$ & $0.0014(0.0006)$ & $0.0010(0.0002)$ & 0.30 & 0.74 \\
\hline \multirow[t]{2}{*}{ Among streams } & $F_{2,48}$ & 0.35 & 1.64 & 0.72 & & \\
\hline & $p$ & 0.71 & 0.20 & 0.49 & & \\
\hline
\end{tabular}


Table 2. Decay coefficients $(k)$ of root diameter size classes $(\mathrm{mm})$ for $1 \mathrm{y}$ within study streams. Data analyzed within and among streams using ANCOVA

\begin{tabular}{|c|c|c|c|c|c|c|c|}
\hline & \multirow[b]{2}{*}{ Stream } & \multicolumn{4}{|l|}{$k \mathrm{~d}^{-1}(\mathrm{SE})$} & \multicolumn{2}{|c|}{ Within streams } \\
\hline & & $0.6-1.0 \mathrm{~mm}$ & $1.0-2.5 \mathrm{~mm}$ & $2.5-5.0 \mathrm{~mm}$ & $5.0-10.0 \mathrm{~mm}$ & $F_{3,64}$ & $p$ \\
\hline & M1 & $0.0014(0.0002)$ & $0.0014(0.0002)$ & $0.0010(0.0002)$ & $0.0011(0.0003)$ & 0.54 & 0.66 \\
\hline & M2 & $0.0016(0.0002)$ & $0.0014(0.0002)$ & $0.0014(0.0003)$ & $0.0013(0.0003)$ & 0.19 & 0.90 \\
\hline & M3 & $0.0010(0.0003)$ & $0.0008(0.0002)$ & $0.0007(0.0003)$ & $0.0012(0.0003)$ & 0.51 & 0.68 \\
\hline \multirow[t]{2}{*}{ Among streams } & $F_{2,48}$ & 1.41 & 0.93 & 2.11 & 0.14 & & \\
\hline & $P$ & 0.25 & 0.40 & 0.13 & 0.87 & & \\
\hline
\end{tabular}

in the current study (Governo et al. 2004). However, decay rates similar to those in this study have been measured for buried litter experiments (particularly where sediments are fine) and intermittent stream studies that have included dry phases during incubations (Mayack et al., 1989; Maamri et al., 2001).

Some disparity exists between findings in streams and forested wetlands on the effects of hydroperiod on litter breakdown. Generally, many stream studies showed that drying slows decomposition, whereas studies on floodplains or temporary wetlands have indicated that continuous flooding results in slower rates than where flooding occurs either a single or multiple pulses (Lockaby et al., 1996; Battle \& Golladay, 2001). Among both types of habitats, low soil moisture will limit microbial growth, however flooding is more likely to lead to anaerobic conditions within standingwater habitats than in streams. Anaerobic conditions result in decomposition of lignin and polysaccharides at $1-10 \%$ the rate associated with aerobic decomposition (Benner et al., 1984). Anaerobic sediment conditions during the beginning of this study and low sediment moisture later probably hampered microbial conditioning. However, we found that leaf decay at wettest site (M3) began more rapidly than the other drier streams, but by the end of the study, rates among the streams did not differ. The labile constituents of leaves (e.g., simple sugars) at M3 may have been more rapidly assimilated than at the drier sites, leaving the more
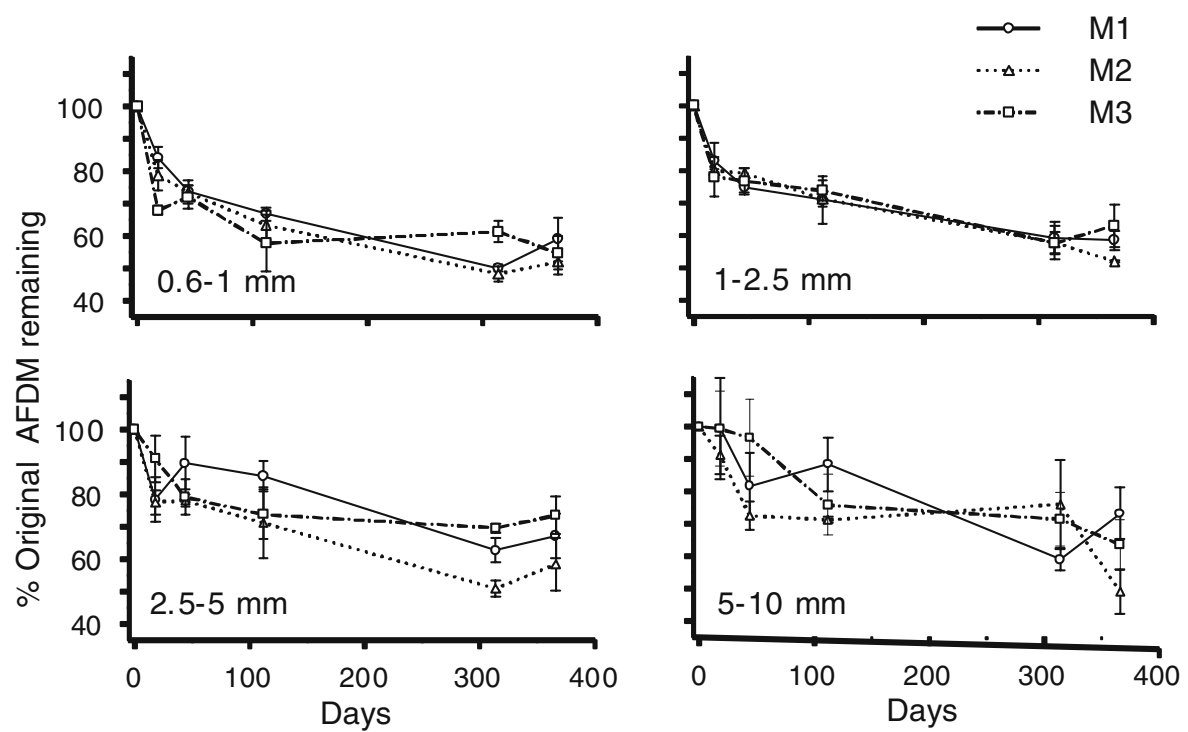

Figure 7. Root breakdown by diameter size class at the study streams over 1 y. Error bars represent 1 SE. 
Table 3. Results of multiple regression models and simple exponential models for each substrate type in the study streams, showing the incremental increases in $R^{2}$ with addition of ecological factors and the $R^{2}$ for the simple exponential relationship between mass loss and date, respectively. All models shown were significant $(p<0.05)$ and no further increase in $R^{2}$ occurred beyond the multiple regression models shown

\begin{tabular}{|c|c|c|c|c|}
\hline Stream & Substrate & Independent variable & Cumulative $R^{2}$ & Exponential $R^{2}$ \\
\hline \multirow[t]{17}{*}{ M1 } & \multirow[t]{6}{*}{ Leaf } & Date & 0.638 & \multirow[t]{6}{*}{0.638} \\
\hline & & Temperature & 0.681 & \\
\hline & & Sediment depth & 0.707 & \\
\hline & & Sediment moisture & 0.708 & \\
\hline & & Redox depth & 0.718 & \\
\hline & & Invertebrate biomass & 0.742 & \\
\hline & \multirow[t]{5}{*}{ Wood } & Date & 0.790 & \multirow[t]{5}{*}{0.755} \\
\hline & & Temperature & 0.797 & \\
\hline & & Sediment depth & 0.797 & \\
\hline & & Sediment moisture & 0.799 & \\
\hline & & Redox depth & 0.804 & \\
\hline & \multirow[t]{6}{*}{ Root } & Date & 0.715 & \multirow[t]{6}{*}{0.736} \\
\hline & & Temperature & 0.727 & \\
\hline & & Sediment depth & 0.775 & \\
\hline & & Sediment moisture & 0.817 & \\
\hline & & Redox depth & 0.849 & \\
\hline & & Invertebrate biomass & 0.852 & \\
\hline \multirow[t]{17}{*}{ M2 } & \multirow[t]{6}{*}{ Leaf } & Date & 0.651 & \multirow[t]{6}{*}{0.609} \\
\hline & & Temperature & 0.657 & \\
\hline & & Sediment depth & 0.694 & \\
\hline & & Sediment moisture & 0.785 & \\
\hline & & Redox depth & 0.786 & \\
\hline & & Invertebrate biomass & 0.788 & \\
\hline & \multirow[t]{5}{*}{ Wood } & Date & 0.827 & \multirow[t]{5}{*}{0.744} \\
\hline & & Temperature & 0.871 & \\
\hline & & Sediment depth & 0.874 & \\
\hline & & Sediment moisture & 0.876 & \\
\hline & & Redox depth & 0.887 & \\
\hline & \multirow[t]{6}{*}{ Root } & Date & 0.735 & \multirow[t]{6}{*}{0.758} \\
\hline & & Temperature & 0.875 & \\
\hline & & Sediment depth & 0.876 & \\
\hline & & Sediment moisture & 0.894 & \\
\hline & & Redox depth & 0.925 & \\
\hline & & Invertebrate biomass & 0.926 & \\
\hline \multirow[t]{9}{*}{ M3 } & \multirow[t]{6}{*}{ Leaf } & Date & 0.623 & \multirow[t]{6}{*}{0.570} \\
\hline & & Temperature & 0.732 & \\
\hline & & Sediment depth & 0.732 & \\
\hline & & Sediment moisture & 0.756 & \\
\hline & & Redox depth & 0.918 & \\
\hline & & Invertebrate biomass & 0.918 & \\
\hline & \multirow[t]{3}{*}{ Wood } & Date & 0.430 & \multirow[t]{3}{*}{0.260} \\
\hline & & Temperature & 0.460 & \\
\hline & & Sediment depth & 0.511 & \\
\hline
\end{tabular}


Table 3. (Continued)

\begin{tabular}{|c|c|c|c|c|}
\hline Stream & Substrate & Independent variable & Cumulative $R^{2}$ & Exponential $R^{2}$ \\
\hline & \multirow{8}{*}{ Root } & Sediment moisture & 0.518 & \multirow{8}{*}{0.556} \\
\hline & & Redox depth & 0.519 & \\
\hline & & Date & 0.558 & \\
\hline & & Temperature & 0.655 & \\
\hline & & Sediment depth & 0.716 & \\
\hline & & Sediment moisture & 0.720 & \\
\hline & & Redox depth & 0.826 & \\
\hline & & Invertebrate biomass & 0.897 & \\
\hline
\end{tabular}

refractory constituents (e.g., lignin, polysaccharides) to decay slowly at all the sites (Carpenter, 1982).

Our prediction that root decay rates would be intermediate between that of leaf and wood was supported through the $112^{\text {th }}$ day of the study, but over the entire study (336 d) no differences were detected among substrate types. Instantaneous decay rates of roots within mesh bags ranged from 0.48 to $1.00 \mathrm{mg} \mathrm{g}^{-1} \mathrm{~d}^{-1}$ across 4 North Carolina swamp communities (Tupacz \& Day, 1990). Our simple linear decay rates for $Q$. nigra roots within channel sediments ranged from 0.79 to $0.94 \mathrm{mg} \mathrm{g}^{-1} \mathrm{~d}^{-1}$ and approximated the $0.91 \mathrm{mg} \mathrm{g}^{-1} \mathrm{~d}^{-1}$ rate measured in the North Carolina mixed-oak swamp community (Tupacz \& Day, 1990). Moreover, we expected that decay rates would be inversely related to root diameter because of differences in surface:volume. Instead, while smaller roots did lose a disproportionately higher percent weight than larger diameter classes, differences were not significant. In a northern hardwood forest, smaller root diameter classes (0.6-1 \& 1.0-2.5 mm) lost more mass than larger classes $(2.5-5.0 \& 5.0-10.0)$ over the first year, but by the second year no differences were detected (Fahey et al., 1988). Weight loss from the buried roots in our study were approximately $2 \mathrm{X}$ higher than first year weight loss from roots in northern upland forests $(\mathrm{McC}$ laugherty et al., 1984; Fahey et al., 1988). Higher soil moisture associated with our study sites and those of wetland communities result in greater decomposition rates and higher turnover, but can limit the depth distribution and therefore overall biomass of roots compared with drier upland systems.

\section{Riparian zone management}

Streambed daily temperature fluctuations were dramatically elevated by removal of the riparian vegetation at M2 compared to the thinned (M1) and control (M3) sub-basins. However, despite these differences we did not observe differences in breakdown rates of buried leaves, roots, or wood over $1 \mathrm{y}$ among the streams. Initially, anaerobic conditions within sediments and, later, low sediment moisture, appeared to override differences in streambed temperature.

The removal of aboveground structures may also have long-term consequences on the input and retention of carbon and streambed stabilization by riparian roots. The filtering role of riparian zone on imported nutrients from the watershed has been well established (e.g., Lowrance et al., 1984), however further work needs to be done to investigate the role of riparian roots in nutrient sequestration within streambed sediments during flowing and dry conditions. Live riparian roots may function as nutrient cycling "hotspots" within predominantly anoxic sediments, likewise dead roots, sloughed root epidermis, and exudates may supplement carbon for denitrification at the oxicanoxic interface (Hedin et al., 1998). Because of their abundance and seasonal connection with downstream perennial reaches, headwater intermittent streams are likely to be important sources of conditioned CPOM to downstream perennial streams. Brinson (1993) argued that "more emphasis should be placed on avoiding impacts to wetlands associated with low-order streams" because they predominate the total length of basins and disturbances of equal area will result in 
greater impact on headwater wetlands than larger downstream wetlands.

\section{Acknowledgements}

We would like to thank A. Bakhityarov and B. Roland for technical assistance, L. Panayotoff and D. Rinella for field assistance, the Southern Forest Nursery Management Cooperative for use of their computer facilities, and two anonymous referees for comments on an earlier draft. This project is funded in part by a cooperative research agreement between the USFS, International Paper, and the Alabama Agricultural Experiment Station.

\section{References}

Battle, J. M. \& S. W. Golladay, 2001. Hydroperiod influence on breakdown of leaf litter in cypress-gum wetlands. American Midland Naturalist 146: 128-145.

Bedfield, E. F., 1996. Leaf breakdown in stream ecosystems. In Hauer, F. R. \& G. A. Lamberti (eds), Methods in Stream Ecology. Academic Press, San Diego, CA: 579-589.

Benner, R., A. E. MacCubbin \& R. E. Hodson, 1984. Anaerobic biodegradation of the lignin and polysaccharide components of lignocellulose and synthetic lignin by sediment microflora. Applied Environmental Microbiology 47: 998-1004.

Böhm, W., 1979. Methods of Studying Root Systems. SpringerVerlag, Berlin 188 pp.

Boulton, A. J. \& P. I. Boon, 1991. A review of methodology used to measure leaf litter decomposition in lotic environments: time to turn over an old leaf? Australian Journal of Marine and Freshwater Research 42: 1-43.

Bridgham, S. D., S. P. Faulkner \& C. J. Richardson, 1991. Steel rod oxidation as a hydrologic indicator in wetland soils. Journal of the Soil Science Society of America 55: 856-862.

Brinson, M. M., 1993. Changes in the functioning of wetlands along environmental gradients. Wetlands 13: 65-74.

Cabrera, M. L., 1993. Modeling the flush of nitrogen mineralization caused by drying and rewetting soils. Journal of the Soil Science Society of America 57: 63-66.

Carpenter, S. R., 1982. Comparison of equations for decay of leaf litter in tree-hole ecosystems. Oikos 39: 17-22.

Fahey, T. J., J. W. Hughes, M. Pu \& M. A. Arthur, 1988. Root decomposition and nutrient flux following whole-tree harvest of northern hardwood forest. Forest Science 34: 744768.

Fiebig, D. M., M. A. Lock \& C. Neal, 1990. Soil water in the riparian zone as a source of carbon for a headwater stream. Journal of Hydrology 116: 217-237.

Gambrell, R. P., R. D. Delaune \& W. H. Patrick, Jr., 1991. Redox processes in soils following oxygen depletion. In Jackson, M. B., D. D. Davies, \& H. Lambers (eds), Plant
Life Under Oxygen Deprivation. SPB Academic Publishing, The Hague, Netherlands: 101-117.

Governo, R., B. G. Lockaby, B. Rummer \& C. Colson, 2004. Silvicultural management within streamside management zones of intermittent streams: effects on decomposition, productivity, nutrient cycling, and channel vegetation. Southern Journal of Applied Forestry 28: 211-224.

Gurtz, M. E., G. R. Marzolf, K. T. Killingbeck, D. L. Smith \& J. V. McArthur, 1988. Hydrologic and riparian influences on the import and storage of coarse particulate organic matter in a prairie stream. Canadian Journal of Fisheries and Aquatic Sciences 45: 655-665.

Hedin, L. O., J. C. von Fischer, N. E. Ostrom, B. P. Kennedy, M. G. Brown \& G. P. Roberston, 1998. Thermodynamic constraints on nitrogen transformations and other biogeochemical processes at soil-stream interfaces. Ecology 79: 684-703.

Henson, K. O., 1996. Estimation of fine root productivity in a forested wetland in southeastern Alabama using two methods. Master's Thesis, Auburn University, Auburn, AL, 62 p.

Herbst, G. N., 1980. Effects of burial on food value and consumption of leaf detritus by aquatic invertebrates in a lowland forest stream. Oikos 35: 411-424.

Hill, B. H., T. J. Gardner \& O. F. Ekisola, 1988. Breakdown of gallery forest leaf litter in intermittent and perennial prairie streams. Southwestern Naturalist 33: 323-331.

Hill, B. H., T. J. Gardner \& O. F. Ekisola, 1992. Benthic organic matter dynamics in Texas prairie streams. Hydrobiologia 242: 1-5.

Jones, R. H., B. G. Lockaby \& G. L. Somers, 1996. Effects of microtopography and disturbance on fine-root dynamics in wetland forests of low-order stream floodplains. American Midland Naturalist 136: 57-71.

Laanbroek, H. J., 1990. Bacterial cycling of minerals that affect plant growth in waterlogged soils: a review. Aquatic Botany 38: 109-125.

Lockaby, B. G., R. S. Wheat \& R. G. Clawson, 1996. Influence of hydroperiod on litter conversion to soil organic matter in a floodplain forest. Journal of the Soil Science Society of America 60: 1989-1993.

Lowrance, R., R. Todd, J. Fail, Jr., O. Hendrickson, Jr., R. Leonard \& L. Asmussen, 1984. Riparian forests as nutrient filters in agricultural watersheds. BioScience 34: 374-377.

Maamri, A., F. Bärlocher, E. Pattee \& H. Chergui, 2001. Fungal and bacterial colonization of Salix pedicellata leaves decaying in permanent and intermittent streams in eastern Morocco. International Review of Hydrobiology 86: 337-348.

Mayack, D. T., J. H. Thorp \& M. Cothran, 1989. Effects of burial and floodplain retention on stream processing of allochthonous litter. Oikos 54: 378-388.

McClaugherty, C. A., J. D. Aber \& J. M. Melillo, 1984. Decomposition dynamics of fine roots in forested ecosystems. Oikos 42: 378-386.

McKevlin, M. R., D. D. Hook \& A. A. Rozelle, 1991. Adaptations of plants to flooding and soil waterlogging. In Waisel, Y. A. A. Eshel, \& U. Kafkafi (eds), Plant Roots: The Hidden Half. M. Dekker, New York, NY: 173-203.

Metzler, G. M. \& L. A. Smock, 1990. Storage and dynamics of subsurface detritus in a sand-bottomed stream. Canadian Journal of Fisheries and Aquatic Sciences 47: 588-594. 
Montague, K. A. \& F. P. Day Jr., 1980. Belowground biomass of four plant communities of the Great Dismal Swamp, Virginia. American Midland Naturalist 103: 83-87.

Roviva, A. D., 1979. Biology of the soil-root interface. In Harley, J. L. \& R. S. Russell (eds), The Soil-Root Interface. Academic Press, NY: 145-160.

Scott, J., 1971. Geologic Map of Monroe County, Alabama. Geologic Survey of Alabama Map no. 101. Tuscoloosa, AL $12 \mathrm{pp}$.

Smock, L. A., 1990. Spatial and temporal variation in organic matter storage in low-gradient, headwater streams. Archiv für Hydrobiologie 118: 169-184.

Tate, C. M. \& M. E. Gurtz, 1986. Comparison of mass loss, nutrients, and invertebrates associated with elm leaf litter decomposition in perennial and intermittent reaches of tallgrass prairie streams. Southwestern Naturalist 31: 511-520.

Tupacz, E. G. \& F. P. Day, 1990. Decomposition of roots in a seasonally flooded swamp ecosystem. Aquatic Botany 37: 199-214.
Van Gestel, M., R. Merckx \& K Vlassak, 1993. Microbial biomass responses to soil drying and rewetting: the fate of fast- and slow-growing microorganisms in soils from different climates. Soil Biology and Biochemistry 25: 109-123.

Vogt, K. A., D. J. Vogt \& J. Bloomfield, 1991. Input of organic matter to the soil by tree roots. In McMichael, B. L. \& H. Persson (eds.), Plant Roots and Their Environment. Elsevier Science, NY: 171-190.

Wallace, J. B. \& J. W. Grubaugh, 1996. Transport and storage of FPOM. In Hauer, F. R. \& G. A. Lamberti (eds.), Methods in Stream Ecology. Academic Publishers, San Diego, CA: 191-215.

Ward, J. V., 1989. The four-dimensional nature of lotic ecosystems. Journal of the North American Benthological Society 8: 2-8.

Whipps, J. M., 1990. Carbon economy. In Lynch, J. M. (ed.), The Rhizosphere. J. Wiley \& Sons, Chichester, U. K: 59-97.

Zar, J. H., 1984. Biostatistical Analysis (2nd ed.). Prentice-Hall, Englewood Cliffs, NJ 